\title{
Basic isoferritin and hypercalcaemia in renal cell carcinoma
}

\author{
GJ MUFTI, TJ HAMBLIN, JOHN STEVENS
}

From the Department of Haematology, Royal Victoria Hospital, Shelley Road, Bournemouth BHI 4JG

SUMMARY A 63-year-old man with iron loss anaemia and hypercalcaemia was found to have a renal cell carcinoma. Despite the iron-deficient blood and bone marrow picture, the serum ferritin concentration was markedly raised. This was mainly due to a "basic isoferritin". The serum parathormone concentration was normal. The serum ferritin and calcium concentrations returned to normal after the tumour was removed. We propose that the renal cell carcinoma cells in this patient secreted the basic isoferritin as well as humoral factor(s) responsible for hypercalcaemia.

Most of the body's ferritin is found intracellularly with only a small amount present in the serum. The tissue ferritins are not homogeneous but consist of families of isoferritins, some of which are common to several tissues.' The molecular heterogeneity of the isoferritins is related to the differences in the proportion of the two subunit types $\mathrm{H}$ and $\mathrm{L}$ in the assembled apoferritin molecule. The technique of isoelectric focusing has helped to distinguish acidic and basic isoferritins. The acidic isoferritins predominate in the normal heart, ${ }^{2}$ pancreas, kidney $^{3}$ and placenta. ${ }^{4}$ The basic isoferritins predominate in the liver and spleen.

The development of sensitive immunoradiometric assay has enabled the measurement of serum ferritin concentrations in various pathological states. The serum ferritin concentration closely mirrors the size of the iron stores in the body. There are, however, conditions in which this relation does not hold. Inappropriately high concentrations of ferritin have been documented in various infections, anaemias of chronic diseases, liver diseases, and in a number of neoplastic disorders including leukaemias, Hodgkin's disease, and malignant tumours of breast, stomach and pancreas. ${ }^{5}$ It has been suggested that the raised serum ferritin in malignant disorders is largely due to presence of acidic isoferritins ${ }^{6}$ and such acidic isoferritins have been termed "oncofetal ferritins" by some authors. ${ }^{2}$ In this report we describe a case of renal cell carcinoma with an iron-deficient blood picture and a very high level of basic isoferritin, a phenomenon

Accepted for publication 2 February 1982 which to our knowledge has not been documented previously. The patient also had hypercalcaemia and high alkaline phosphatase activities. All these abnormalities returned to normal after the tumour was removed.

\section{Case report}

A 63-year-old man presented in August 1981 with a history of weight loss of three stones $(19 \mathrm{~kg})$ in six months, shortnesss of breath on moderate exertion and tiredness of two month's duration. On systematic enquiry he admitted to polyuria, polydypsia and constipation which had gradually been getting worse over two weeks. Previous medical history was unremarkable and he was not taking any medication. On examination he was pale, dehydrated and pyrexial $\left(37 \cdot 8^{\circ} \mathrm{C}\right)$. Examination of the abdomen revealed 2 $\mathrm{cm}$ hepatomegaly. The spleen and kidneys were not palpable, there were no masses and the rest of the examination was normal. Urine analysis showed microscopic haematuria. Investigations revealed $\mathrm{Hb}$ $9.0 \mathrm{~g} / \mathrm{dl}, \mathrm{MCV} 70 \mathrm{fl}, \mathrm{MCH} 20.9 \mathrm{pg}, \mathrm{MCHC} 29.7$ $\mathrm{g} / \mathrm{dl}$, WBC $10 \cdot 1 \times 10^{9} / 1$, platelet count $574 \times 10^{9} / 1$, ESR $105 \mathrm{~mm} / 1 \mathrm{st}$ hour and the film showed micro- $\sigma$ cytic hypochromic red cell morphology. Blood urea, N electrolytes, chest $x$-ray and ECG were normal. N Other biochemical tests showed bilirubin $9 \mu \mathrm{mol} / \mathrm{l}$ (NR < 17), AST 9 IU/l (NR < 18), LDH 46 IU/l $(\mathrm{NR}=30-90)$, total protein $67 \mathrm{~g} / \mathrm{l}(\mathrm{NR}=60-80)$, albumin $30 \mathrm{~g} / \mathrm{l}(\mathrm{NR}=35-47)$, alkaline phosphatase $323 \mathrm{IU} / \mathrm{l}(\mathrm{NR}=30-90)$, corrected serum calcium $2.98 \mathrm{mmol} / \mathrm{l}(\mathrm{NR}=2.25-2.62)$, inorganic phosphate $1.11 \mathrm{mmol} / \mathrm{l}(\mathrm{NR}=0 \cdot 8-1 \cdot 6)$, serum para1008 
thormone $75 \mathrm{pg} / \mathrm{ml}(\mathrm{NR}<120)$, serum iron 4 $\mu \mathrm{mol} / \mathrm{l}(\mathrm{NR}=11-25)$, iron-binding capacity 24 $\mathrm{mmol} / \mathrm{l}(\mathrm{NR}=45-72)$, serum ferritin $1900 \mu \mathrm{g} / \mathrm{l}(\mathrm{NR}$ $=15-400 \mu \mathrm{g} / \mathrm{l})$. Bone marrow aspirate showed a moderately hypercellular marrow with micronormoblastic maturation of erythroid precursors, myelopoesis was normal and megakaryocytes were slightly increased in numbers. Marrow iron stores were absent. An intravenous pyelogram showed an irregularity and poor filling of the left pelvicalyceal system and upper part of the ureter on that side. An abdominal ultrasonic scan showed a solid mass approximately $6 \mathrm{~cm}$ in diameter in the left kidney. Echo patterns from the liver, pancreas and other abdominal organs were normal. Skeletal survey, $x$-rays of hands, serum 5 nucleotidase and acid phosphatase activities, Tc 99 liver and spleen scan, faecal occult bloods, serum protein electrophoresis, immunoglobulins and autoantibody profile gave normal or negative results.

A diagnosis of a left-sided kidney tumour was made. The hypochromic blood picture, serum iron and the absence of marrow iron stores were consistent with iron loss anaemia, whereas the total ironbinding capacity and the high serum ferritin concentrations did not support this diagnosis. However the high serum ferritin could have been due to the secretion of an isoferritin by the kidney tumour and further analysis of the serum ferritin was performed to determine the isoferritin present.

\section{SPECIAL INVESTIGATIONS}

Using specific spleen and heart isoferritin antisera, basic and acidic isoferritin concentrations were determined in the patients serum and the eluates after anion exchange chromatography. Spleen type (basic) isoferritin was markedly raised at $1906 \mu \mathrm{g} / \mathrm{l}$, whereas the heart type (acidic) isoferritin level was within normal limits at $47 \mu \mathrm{g} / \mathrm{l}$. The ferritin eluted from the anion exchange columns at a chloride ion concentration of $0 \cdot 1 \mathrm{M}$. This affinity pattern is typical of the serum ferritin from patients with iron overload which is immunologically similar to liver and spleen ferritin and has no reactivity with antibodies to heart ferritin. ${ }^{7}$ Ferritin was partially purified from a litre of patients plasma obtained by exchanging patients plasma for the same volume of plasma protein fraction, using the Haemonetics 30 Celltrifuge. The method of purification included heat treatment and gel filtration on Sepharose 6B as described previously by Worwood et al. ${ }^{7}$ The partially purified preparation of ferritin was divided into two, half was incubated with neuraminidase and half with buffer as described by Cragg et al ${ }^{8}$ The preparation which was not enzyme-treated showed a range of isoferritin on isoelectric focusing. These included isoferri- tins with isoelectric points similar to those of heart ferritins. However, the enzyme-treated preparation contained only the most basic isoferritins. This finding coupled with the low level of heart type isoferritin, suggest that the rise in serum ferritin was mainly due to the most basic isoferritins.

The glycosylation of the ferritin present in the patient's serum was determined by its binding to concanavalin A (Con A). Only $16 \%$ of the serum ferritin was bound to Con A (normal range 50$70 \%$ ) and this low binding is suggestive of tissue damage and release of ferritin from damaged cells. ${ }^{9}$

\section{TREATMENT AND PROGRESS}

He was treated initially with rehydration. However, one week after admission he became drowsy and his serum calcium rose to $3.8 \mathrm{mmol} / \mathrm{l}$, so that he was started on high doses of prednisolone. His general condition improved and a laparotomy performed three weeks after admission revealed an $8 \mathrm{~cm}$ solid mass arising from the left kidney. There were no obvious metastases and a left ureteronephrectomy and adrenalectomy was performed. Histology of the tumour was that of renal cell carcinoma with invasion of the left renal vein although the paraortic lymph nodes and left adrenal gland were normal. He was transfused with six units of blood prior to and during surgery. His post-operative course has been uneventful and serum calcium, alkaline phosphatase, albumin and blood picture have returned to within normal limits.

Serial estimations of the serum ferritin postoperatively have demonstrated a persistent fall. The serum ferritin level two weeks after the operation was $800 \mu \mathrm{g} / \mathrm{l}$ and six weeks after the operation was $450 \mu \mathrm{g} / \mathrm{l}$, although by this time his iron stores may have been raised as a result of the blood transfusion.

\section{Discussion}

The exact origin of the ferritin in the serum of patients with cancer is not clear. However, some studies have produced evidence for increased synthesis of ferritin by leukaemic blast cells and by malignant cells from carcinoma of the bronchus and acute monoblastic leukaemia. ${ }^{10-12}$ In this respect it has been suggested that in some patients with malignant disease the serum ferritin may represent a tumour associated antigen and once a high concentration of serum ferritin has been found its measurement may be useful in the follow-up of these patients. The serum ferritin concentration in our patient was markedly raised on presentation, which in the presence of depleted marrow iron stores, low serum iron levels, and microcytic hypochromic red cell morphology, is consistent with inappropriate release of 
ferritin. The ferritin concentrations fell progressively after the removal of the kidney tumour. Therefore, it seems likely that if the plasma ferritin was derived from the kidney tumour, then the tumour was releasing or secreting the isoferritins.

Antibodies with a high degree of specificity either for the more basic or the acidic ferritin from normal human tissues, have provided a means of distinguishing between basic and acidic isoferritins in serum. Hazard and Drysdale produced an antibody against Hela cell ferritin, which is acidic in character, and applied this antibody to the assay of ferritin in patients with a variety of malignant conditions. ${ }^{\circ}$ Their results suggested that serum acidic isoferritins were considerably higher than the basic isoferritins in malignancy. However, Jones and his colleagues were unable to confirm these findings. ${ }^{1314}$ These differences and the microheterogeneity of the ferritins may partly be explained by the degree of glycosylation of ferritins rather than the variation in the subunit composition. ${ }^{15}$ In our patient we were unable to detect increased concentrations of acidic ferritin with antibodies to heart ferritin by direct assay or with measurements of eluates after anion exchange chromatography of the serum. In fact most of the ferritin elution was consistent with a predominance of basic isoferritin. Moreover the enzyme-treated portion of the partially purified ferritin preparation in our patient showed the presence of only the most basic isoferritins. It is therefore likely that the kidney tumour in this patient was releasing a predominantly basic isoferritin.

Why this patient had hypercalcaemia is unclear. We presume that the tumour secreted a humoral factor(s), the nature of which remains undetermined. Hypercalcaemia has been reported in $5-10 \%$ of patients with renal cell carcinoma. There are reports that definite, although low concentrations of immunoreactive parathormone are detected in the blood of patients with malignant tumours and accompanying hypercalcaemia. However, it is uncertain whether defects such as release of predominantly proparathormone or preparathormone (caused by lack of specific cleavage enzymes) or peptide fragments of the hormone caused by excessive proteolytic digestion might be found in states of uncontrolled parathormone secretion. ${ }^{16}$ Greenberg $e t$ al have detected immunoreactive peptides produced by hypernephroma cells in in vitro culture. ${ }^{17}$ In addition there is some evidence that excessive production of prostaglandins particularly of the E series by some tumours can lead to hypercalcaemia. ${ }^{18}$ Although the exact biochemical basis of this patient's hypercalcaemia is uncertain, it is quite clear that it corrected itself after the removal of the tumour.

We thank Mrs SJ Cragg, Mr BM Jones and Dr M Worwood of the Department of Haematology, Welsh National School of Medicine, for studies on the properties of the serum ferritin.

\section{References}

' Drysdale JW, Thomas GA, Arosio P, et al. Human isoferritins in normal and disease states. Semin Hematol 1977;14:71-88.

${ }^{2}$ Alpert E, Coston RL, Drysdale JW. Carcinofetal human liver ferritins. Nature 1973;242:194.

${ }^{3}$ Powell LW, Alpert E, Isselbacher KI, et al. Human isoferritins: organ specific iron and apoferritin distribution. $\mathrm{Br} \mathrm{J} \mathrm{Haematol}$ 1975;30:47.

${ }^{4}$ Drysdale JW, Singer RM. Carcinofetal human isoferritins in placenta and Hela cells. Cancer Res 1974;34:3352.

${ }^{5}$ Worwood M. Serum ferritin. In: Jacobs A, Worwood M, eds. Iron in biochemistry and medicine II. London and New York: Academic Press, 1980.

${ }^{\circ}$ Hazard JT, Drysdale JW. Ferritinaemia in cancer. Nature 1977;265:755-6.

${ }^{7}$ Worwood $\mathrm{M}$, et al. The purification and properties of ferritin from human serum. Biochem J 1976;157:97-103.

${ }^{8} \mathrm{Cragg}$ SJ, et al. Detection of a glycosylated subunit in humas serum ferritin. Biochem J 1981;199:565-71.

${ }^{9}$ Worwood $\mathrm{M}$, et al. Binding of human serum ferritin to con canavalin A. Clin Sci 1979;56:83-7.

${ }^{10}$ Gropp C, Havemann K, Lehman FG. Carcinoembryonic antigen and ferritin in patients with lung cancer before and during therapy. Cancer 1978;42:2802-8.

"Yoda Yasuhiro, Tsukasa Abe. Acute monocytic leukaemia cell isoferritin. Cancer 1980;46:289-92.

${ }^{12}$ White GP, et al. Ferritin synthesis in normal and leukaemic leucocytes. Nature 1974;250:584-6.

${ }^{13}$ Jones BM, Worwood M. An immunoradiometric assay for the acidic ferritin of human heart: application to human tissues, cells and serum. Clin Chim Acta 1978;85:81-8.

14 Jones BM, Worwood M, Jacobs A. Serum ferritin in patients with cancer: determination with antibodies to Hela cell and spleen ferritin. Clin Chim Acta 1980;106:203-14.

${ }^{15} \mathrm{Cragg} \mathrm{SJ}$, et al. Sialic acid and the microheterogeneity of human serum ferritin. Clin Sci 1980;58:259-62.

${ }^{16}$ Habener JF, Potts JT. Biosynthesis of parathyroid hormones. $N$ Engl J Med 1978;299:635-44.

${ }^{17}$ Greenberg PB, Martin TJ, Sutcliffe HS. Synthesis and release of parathyroid hormone by a renal carcinoma in cell culture. Clin Sci Mol Med 1973;45:183-91.

${ }^{18}$ Seyberth HW, Segre GV, Morgan JL, et al. Prostaglandins as mediators of hypercalcaemia associated with certain types of cancer. N Engl J Med 1975;293:1278-83.

Requests for reprints to: Dr GJ Mufti, Department of Haematology, Royal Victoria Hospital, Shelley Road, Bournemouth BH1 4JG, England. 